\title{
A Preliminary Pharmacognostical and Physico-Chemical Assay of Shalmali moola Granules
}

\author{
Research Article
}

\section{Remesh Chandran T S ${ }^{*}$, Manu R², Vishnu B ${ }^{3}$}

1. P.G. Scholar, 2. Professor, 3. Assistant Professor,

Department of Kayachikitsa, Parul Institute of Ayurved, Parul University, P.O. Limda, Vadodara.

\begin{abstract}
Ayurveda is concerned with the maintenance of life and the healing of illnesses that present themselves in the human body. Several herbal and Herbo mineral preparations have been explained in Ayurveda for the treatment of disease. Standardization is necessary to ensure batch to batch consistency, as well as for routine drug preparation on a large scale. Modification of old dosage forms and development of new dosage forms is an evolving process that leads significantly to the flourishing of science with a transforming lifestyle and people's interest. The preparation of granules consists of a refined form of Ghana (solid herbal extract preparation) and Khanda Kalpana (solid preparations similar to granules). Shalmali moola granule is a formulation for its beneficial properties such as, Balya (immuno-modulators), Rasayana (rejuvenator), Vajikarana (aphrodisiac) etc. Present study has elaborated standardization, physio-chemical parameters, Qualitative analysis and Chromatography (HPTLC) of Shalmali moola granules. Granules were prepared by adopting reference of Bhaishjya Rantavali and This study will be useful for standardization of Shalmali moola granule and for the preparation of the monography of this formulation for the Ayurvedic Formulary of India (AFI).
\end{abstract}

Key Words: Shalmali moola granules, Standardization methods, Vajikarana.

\section{Introduction}

Revolutionary dosage formulations have also been contributed by Bhaishjya Kalpana, the pharmaceutical manufacturing sector of Ayurveda. Under the Ghana Kriya outlook, Avaleha and Kahanda Kalpana's are considered where the semi-solid to solid dosage type is described (1). It is often necessary to transform the dosage type to more acceptable for modern times with additional advantages of palatability and presentation. Shalmali is a possible medication with properties such as Balya (immunomodulator), Rasayana (rejuvenator), Vajikarana (aphrodisiac) (2) etc. It is therefore necessary to carry out a quality evaluation of the formulation. The lack of specific quality management criteria for herbal medicines and their formulations is one of the big issues faced by Ayurveda doctors. In India, the Government of India Department of AYUSH has initiated a central scheme to establish basic operating procedures for the development process in order to develop requirements for pharmacopoeia for Ayurvedic preparations. In today's global market to be relevant, a formula has to be standardised in order to accomplish global acceptance. This formulation has

\section{* Corresponding Author:}

\section{Remesh Chandran T S}

PG Scholar, Department of Kayachikitsa,

Parul Institute of Ayurved,

Parul university, P.O Limda,

Vadodara-391760. India.

Email Id: remeshchandran39@gmail.com been explained in classics for the management of Ksheena shukra (3). In this present study, Shalmali moola granules was prepared following the standard operating procedures in GMP certified pharmacy. This formulation is commonly used in clinical practice for the treatment of Shukra dhatugata Vikara. Since the therapeutic values and efficacy of the formulation depend on the several aspects, the present study has taken up for pharmaceutical analysis. Standardization of the Shalmali granules was being carried out and quality assurance standards have been studied.

\section{Aim and Objectives}

- Identification and authentication of raw drugs used for Shalmali moola granules

- Preparation of Shalmali moola granules at GMP certified pharmacy.

- Physicochemical, phytochemical and HPTLC analysis of Shalmali moola granules.

\section{Materials and methods \\ Collection of plant material}

Raw drug of Shalmali Moola was collected from FARMERS AYURVEDA PHARMACY, GMP Certified Agency, Kottarakara, Kollam.

Identification and Authentication of plant material Raw drug Identification and Authentication by CARe KERALAM LIMITED, DSIR \& NABL Accredited Lab, Thrissur, Kerala. 


\section{Method of preparation of Shalmali granules}

Preparation of Shalmali moola Granules was carried out at GMP certified Parul Ayurved Pharmacy, Parul University, Limda, Waghodia, Vadodara. Raw drug of Shalmali moola was collected \& cleaned, then it was sliced down into small pieces. It was dried under shade for 3-4 weeks to get rid of moisture content in order to avoid spoilage. At the end of 4th week when moisture content was completely lost, the raw drug become stiff \& light weight. Then it was put into the disintegrator to reduce the particle size, then it was shifted to micro pulverizer machine to reduce the particle size to sukshma choorna. Then the obtained sukshma choorna was shifted to vibro shifter and filtered through sieve no 60. A clean and dry steel container was taken and little amount of melted gritham was added to it, then sukshma choorna was added and mixed well.

About $20 \mathrm{~kg}$ of Khanda sharkara was taken and it was fed into the pulverizer to crush them into fine powder, which was collected in a clean and dry steel vessel and 5 litres of water was added to it and loaded onto a burner. It was heated on a constant temperature till it melts. The temperature was kept constant throughout the melting process between 90- 100 degree Celsius. The process was monitored carefully and once it attained paka i.e., Thanthu paka (Thread like consistency), the ghrita bharjitha sukshma choorna was added to it and stirred uniformly. Lastly, lump was made out of the mixture, then it was passed through sieve no 24 to obtain granules. Then the obtained granules were spread on a clean and dried steel tray and kept in a hot air oven at a temperature of 40 degree Celsius about 3-4 hours. These dried granules collected and stored in wide mouth food grade plastic container (4).

\begin{tabular}{l|l|l|l|} 
Table no 1: & Ingredients of Shalmali moola granules \\
\hline $\begin{array}{l}\text { Name of } \\
\text { Drug }\end{array}$ & $\begin{array}{l}\text { Botanical } \\
\text { name }\end{array}$ & Used part & $\begin{array}{l}\text { Quantity } \\
\text { taken }\end{array}$ \\
\hline $\begin{array}{l}\text { Shalmali } \\
\text { Shalmalia }\end{array}$ & $\begin{array}{l}\text { Malabarica } \\
\text { manda }\end{array}$ & Moola & $5 \mathrm{~kg}$ \\
\hline $\begin{array}{l}\text { Kharkara } \\
\text { Sater }\end{array}$ & - & - & $20 \mathrm{~kg}$ \\
\hline Wate & - & - & 5 liters \\
\hline
\end{tabular}

\section{Methods of evaluation of Shalmali moola granules}

Shalmali moola granule was analysed by using standard qualitative and quantitative parameters. All the procedures were conducted at CARe KERALAM LIMITED, DSIR \& NABL Accredited Lab, Thrissur, Kerala.

\section{Organoleptic characters}

It includes parameters like colour, taste, touch, consistency (5).

\section{Physio-Chemical Analysis}

It includes parameters like $\mathrm{pH}$, Loss on Drying, total ash, acid insoluble ash, water soluble extractive, alcohol soluble extractive, (6).

\section{Qualitative analysis}

The qualitative analysis of Shalmali moola granules was done for Glycoside Sugar, Alkaloids, Tannins, Flavonoids, Gallic acid, Ascorbic Acid, Saponin, Starch (7).

\section{Chromatography}

HPTLC (high-performance thin layer chromatography) is a sophisticated form of TLC, which works same principles as that TLC i.e., the principle of separation is adsorption. High performance thin layer chromatography (8) (HPTLC) gives much greater resolution and separation of components than normal TLC, it uses chromatographic stationary phases with excellent separation efficiency and employs state of the art instrumentation for all steps in the procedure. Method and other procedures followed for HPTLC of Shalmali moola granules is being discussed below.

\section{Results and Discussion}

The formulation Shalmali moola granules was prepared following standard operating procedures in GMP certified pharmacy and was subjected for qualitative and quantitative analysis. The pharmaceutical analysis results were discussed below.

\section{Organoleptic evaluation}

The organoleptic parameters are the basic criteria for selecting raw ingredients and confirming the quality of the finished formulation. The texture of the finished formulation was found to be smooth, indicating surface uniformity without cracks. The colour was Dark brown, the taste was Sweet and the smell was slightly aromatic and characteristic due to the special properties of the ingredients used. All the details have been given in table 2 .

\begin{tabular}{|c|c|c|}
\hline & & \\
\hline SI no & Characters & Observation \\
\hline 1 & Colour & Dark brown colour \\
\hline 2 & Odour & Aromatic \\
\hline 3 & Taste & Sweet \\
\hline 4 & Consistency & Solid \\
\hline
\end{tabular}

\section{Physio-Chemical Analysis of Shalmali moola granules \\ Loss on drying}

Drying between samples indicates that the samples are devoid of excess water content and that there is no microbial overgrowth or insect infestation. In the sample of Shalmali moola granules loss of drying was found to be $1.76 \%$, which means that the samples have a good shelf-life and will not decay when stored.

\section{Total ash and acid insoluble ash}

It provide information on contamination, substitution, adulteration. Low total ash and acid insoluble ash means low levels of inorganic matter and Contents of silica. In this sample, the value of Shalmali moola granules Total Ash was $2.34 \%$, \& Acid insoluble 
Ash $0.52 \%$ which was slightly higher and may be due to the presence of fibre's and sclereids in the ingredients.

\section{Water and Alcohol soluble extracts}

Water soluble extract and Alcohol soluble extract were $60.61 \%$ and $26.18 \%$ respectively in the sample of Shalmali moola granule. The high solubility of the sample in water indicates that the drug is best suited for extraction with water or water-based preparations. The negligible presence of Volatile oils is also in favour of thermal extraction with water.

\section{pH}

The $\mathrm{pH}$ is measured to detect the acidity or alkalinity of the aqueous solution of the drug, which helps to understand the pharmacological basis of drug absorption and metabolism. In this sample, Shalmali moola granules $\mathrm{pH}$ was 4.9 percent, therefore, it is clear that the drug tested was acidic in nature. All the details have been given in table 3 .

Table 3: Physico-Chemical Analysis of Shalmali moola granules

\begin{tabular}{|c|l|c|}
\hline SI no & \multicolumn{1}{|c|}{ Parameters } & \multicolumn{1}{|c|}{ Value } \\
\hline $\mathbf{1}$ & Loss on drying & $1.76 \%$ \\
\hline $\mathbf{2}$ & Acid insoluble ash & $0.52 \%$ \\
\hline $\mathbf{3}$ & Total ash & $2.34 \%$ \\
\hline $\mathbf{4}$ & Alcohol soluble extracts & $26.18 \%$ \\
\hline $\mathbf{5}$ & Water soluble extracts & $60.61 \%$ \\
$\mathbf{6}$ & $\mathrm{pH}$ & $4.9 \%$ \\
\hline
\end{tabular}

\section{Qualitative Analysis: Phytochemical screening}

Shalmali moola granules was subjected for the qualitative analysis to identify the active principles of the formulation which shows presence of Carbohydrates, Saponin Glycoside, Flavonoids and Steroids as shown in table 3.

\begin{tabular}{|c|c|c|}
\hline \multicolumn{3}{|c|}{$\begin{array}{l}\text { Table 4: Qualitative Analysis: Phytochemica } \\
\text { screening of Shalmali moola granules }\end{array}$} \\
\hline SI no & Parameters & Results \\
\hline 1 & Carbohydrate & +++ \\
\hline 2 & Starch & - \\
\hline 3 & Protein & - \\
\hline 4 & Amino acids & - \\
\hline 5 & Tannin \& Polyphenols & - \\
\hline 6 & Saponin Glycoside & + \\
\hline 7 & Alkaloids & - \\
\hline 8 & Flavonoids & ++ \\
\hline 9 & Steroids & + \\
\hline 10 & Triterpenoids & - \\
\hline
\end{tabular}

High-Performance Thin Layer Chromatographic Study

Chromatography

It was carried out at Care Keralam Limited, Thrissur. HPTLC fingerprinting report was done to analyze the finished formulation Shalmali moola granules.

\section{Apparatus}

HPTLC was done using a computerized densitometer scanner 3 with multiwavelength scanning capability, which was managed by winCATS planar chromatography manager version 1.4.2 (CAMAG, Switzerland). A rotating evaporator (Bukhí, Switzerland) equipped with an automobile vacuum controller was used for drying and concentration. For standard testing and solutions, the ultrasound bath (Enertech, Mumbai, India) was employed.

\section{Extraction and Test Sample Preparation}

$1 \mathrm{~g}$ Shalmali granules were extracted for 5 hours with a methanol content of $20 \mathrm{~mL}$. Upon the completion of 5 hours. The extract was filtered through filter paper, and the remaining Shalmali granules were washed three times with the solvent system $(5 \mathrm{~mL}$ each time). This solution was used as a control sample for quantification.

\section{Methodology}

Three methanol extracts from the same batch of Shalmali granules underwent HPTLC evaluation. 4 microlitres of the extract were spotted as bands of length $6 \mathrm{~mm}$ at a distance of $10 \mathrm{~mm}$ on an HPTLC silica gel 60F 254 (Merck) plate. Toluene: Ethyl Acetate: Formic acid (5:1.5:0.5) was used to develop the plates in the CAMAG twin-trough glass chamber, which had previously been saturated with the solvent for 30 minutes. After experimenting with various solvent systems of variable polarity, the mobile phase was selected. After development, the plates were dried in an oven at 60 degrees Celsius and scanned in absorbance mode with a CAMAG TLC Scanner. The data was processed using the winCATS planar chromatography management program, at $254 \mathrm{~nm}$ and $366 \mathrm{~nm}$ compounds were scanned.

\section{Results}

After derivatization, plate was examined for appearance of different bands at different Rf. and following were the findings:

Details of HPTLC profile of all tracks @ 254 $\mathrm{nm}$ : Under the $254 \mathrm{~nm}$ wavelength-Track -T1 of Shalmali moola granules, 6 spots were detected and starts with respect to retardation factor $0.04,0.17,0.23,0.46,0.59$ and 0.78 .

Details of HPTLC profile of all tracks at 366 $\mathrm{nm}$. Under the $366 \mathrm{~nm}$ wavelength-Track -T1 of Shalmali moola granules, 6 spots were detected and starts with respect to retardation factor $0.03,0.17,0.28,0.38,0.49$, and 0.74 .

HPTLC, which was generated @254 nm and (a) $366 \mathrm{~nm}$ after the derivatization, revealed that the presence of 6 spots in both tracks of wavelength respectively. Thus, the formulation is rich in phytoconstituents.

\section{Discussion}

Ayurvedic health care system is increasingly being used to treat a variety of health issues, particularly lifestyle diseases. The ingredients were identified and authenticated pharmacognostically before being used in the formulation. Any plant or formulation 
Remesh Chandran T S et.al., A Preliminary Pharmacognostical and Physico Chemical Assay of Shalmali moola Granules

used medicinally needs a thorough investigation prior to use, as therapeutic effectiveness is dependent on the consistency of the ingredients used in the medicinal product's preparation. Physicochemical analysis, qualitative analysis, and HPTLC were performed on the prepared drug Shalmali granule. Shalmali granule ingredients are Shalmali moola, khanda sharkara and gritham.

Three methanolic samples of the granules were subjected to HPTLC analysis which generated a fingerprint, wherein similarity in number, RF, intensity and colour of bands were obtained, showing that the active constituents present were similar and helped to establish it. HPLTC analysis using toluene: ethyl acetate: formic acid (5:1:5:0.5) mobile phase was found suitable for consistency evaluation of the granules. All these parameters may be employed as standard reference for quality control analysis of the formulation.

\section{Conclusion}

The study revealed that sufficient quality control parameters were maintained throughout the process of the preparation of Shalmali moola granules. The prepared samples were comparatively analysed by following parameters such as organoleptic characters, Physico-chemical parameters, Phyto chemical analysis and chromatographic study. The results obtained were very similar in each parameter in the sample. The chromatogram obtained in three methanol extractives have indicated similar values. The groundwork requirements for standardization of Shalmali moola granules been attempted in this study. In the future, this study will help to standardize Shalmali moola granules and to prepare the monograph of this for Ayurvedic Formula of India (AFI).

\section{References}

1. Shastri. A, Bhaishajya Ratnavali. 18 th edition.Varanasi, Chaukhambha Sanskrit Sansthana publisher; 2005. 464p.

2. Rao G P. Bhaishajya ratnavali of Kaviraj. $1^{\text {st }}$ edition. Varanasi, Chaukhamba Orientalia publisher; 2002. 530p.

3. Shastri. A, Bhaishajya Rathnavali 18 th edition. Varanasi chaukhambha Sanskrit Sansthana publisher; 2005: 728p.

4. Kaviraja Ambikadatta Shastri. Vidyotini Hindi Commetary Analysis with Appendixes, 32nd edition. Varanasi, Chaukhambha Sanskrit Sansthana publisher, 2005; 55:13-17

5. The Ayurvedic Pharmacopeia of India. Government of India. Part I. $1^{\text {st }}$ ed. Vol. I. Apx-2. New Delhi: Controller of Publications; 1999. p. 237.

6. The Ayurvedic Pharmacopeia of India. Government of India. Part I. 1 $1^{\text {st }}$ ed. Vol. I. Apx-2. New Delhi: Controller of Publications; 1999. p. 238.

7. Pulok K. Mukherjee, Quality Control and Evaluation of Herbal Drugs, $1^{\text {st }}$ edition, Amsterdam Netherlands, Elsevier Science publisher, 2019, p. 455-458.

8. Hildebert Wagner \& Sabine Bladt, Plant Drug Analysis: A Thin Layer Chromatograph Atlas, $2^{\text {nd }}$ edition, Berlin, Springer publisher, 2009, p.604-608. 